\title{
The role of maintenance therapy in the treatment of elderly non-small- cell lung cancer patients: a meta-analysis of randomized controlled trials [Corrigendum]
}

Zhang L, Gao S, He J. Drug Des Devel Ther. 2017;11: 3435-3440.
On page 3435, the first author's name was incorrectly listed as Liangzhe Zhang. His correct name is Liangze Zhang.
Drug Design, Development and Therapy is an international, peerreviewed open-access journal that spans the spectrum of drug design and development through to clinical applications. Clinical outcomes, patient safety, and programs for the development and effective, safe, and sustained use of medicines are the features of the journal, which has also been accepted for indexing on PubMed Central. The manuscript management system is completely online and includes a very quick and fair peer-review system, which is all easy to use. Visit http://www.dovepress.com/testimonials.php to read real quotes from published authors. 